\title{
METHODOLOGICAL FOUNDATIONS OF MILITARY PSYCHOLOGY AND PSYCHOLOGICAL SECURITY
}

\author{
Yuri P. Zinchenko, \\ Aleksander N. Veraksa, \\ Sergey V. Leonov \\ Lomonosov Moscow State University
} Moscow

\begin{abstract}
The article is devoted to the history of development of military psychology from psychological and philosophical positions. The transition stage in development of military psychology from classical to postclassical type of rationality is focused. Analysis of combat activity as self-regulation system is presented. The latest technologies in solving key problems of military science are discussed.
\end{abstract}

Keywords: military psychology, psychological security, history of psychology

Military psychology can be defined as an area of the study and application of psychological principles and methods to the military environment (Mangelsdorff \& Gal, 1991). C. Cronin compares military psychology with a microcosm which embraces psychological disciplines and which affects almost all aspects of military setting (Cronin, 2003).

G.P. Krueger distinguishes the following aspects of psychological research in military settings: 1) recruitment, selection, placement, training and retention of military personnel; 2) prediction and enhancement of combatant performance in harsh environments; 3 ) human engineering design of complex weapon systems for effective use by soldiers, sailors, airmen and marines; 4) training procedures to mold well-honed military teams by maximizing specialized differential skills to permit success on tough missions; 5) soldier coping mechanisms for deployment to foreign lands, or to carry out extended hours of work, or to work in austere conditions; 6) soldier's abilities to adjust to countless intricacies 
of military life-style; 7) collection and interpretation of large amounts of behavioural and psychological data to assist military leaders and civilian authorities in making smart decisions and informed policies that affect millions of military members and their families; 8) providing advice on integrating people of diverse ethnic and social backgrounds into the workplace.

Methodology of military psychology is inseparably linked with formation of psychological and military science. There is a transition in development of military psychology from classical to postclassical type of rationality. In the first place classical psychological science is aimed at providing knowledge and involves the exclusion of the psychological cognition of personal values and goals as factors affecting the objectivity of knowledge. In early works devoted to military psychology the influence of associative psychology is clearly traced. Thus, A. Zykov reasoning about foundations of human awareness of his/her behaviour gives the dominant role of force sensations, ideas, process of associations, irradiation of sensation tone. In a similar paradigm the research was conducted by N.I. Bondarev in 1920. The purpose of it was to study combat experience of soldiers who received minor injuries. N.I. Bondarev conducted 229 associative experiments in which soldiers described their feelings, the nature of associations, their rate of occurrence etc. Without concentrating on these findings we will note the fact of the reference to the personalities of the soldiers who had experience in actual combat operations. Formulation of the problem of studying the personality of a warrior required a different approach.

The classical ideal of rationality is presented by physiological researches in military sphere. In 1920-30s the behavioural tendencies appeared in military psychology, for example, the studying of psychophysiological features of soldiers' behaviour and their emotional reactions. In his work "Foundations of military psychology" H. Hahanyan described the physiological shifts under such cognitions as fear, panic and formulated the principles of military training. A. Talankin emphasizes the role of self-awareness during the combat, however, he focuses attention on J. Watson's research of understanding the emotions of fear and anger.

Non-classical psychological science introduced new criteria of cognition: necessity to consider the method used to obtain data, the adoption of relativism in reference of existing scientific paradigms. 
It stresses the dependence of the resulting knowledge from the social context and a number of other factors that regulate the organization of complex self-regulating systems. According to V.S. Stepin "if within the mechanical picture of the world the things (bodies) served as something primary, e.g. a substrate, processes would be interpreted as the effect of one thing to another by transfer of power that in a new system of representations of every thing appeared as procedural system, self-reproducing as a result of its interaction with the environment and through self-regulation".

World War I marked the official emergence of military psychology. R. Yerkes wrote in 1917, "It is obviously desirable that the psychologists of the country act together in interests of defense. Our knowledge and our methods are of importance to the military affairs of this country and it is our duty to work together to maximize the effective work aimed at increasing the efficiency of our army and navy" (Yerkes, 1918). At the initial stage psychologists found their niche in the selection and classification of military recruits. Testing of intelligence during World War I was the task that resulted in L.Terman to focus on the role of standardized administration of psychological tests.

Rapid growth of military psychology during the Great Patriotic War of 1941-1945 was due to particular goals which were set before psychologists: to strengthen the morale of soldiers, to raise their fighting spirit, to develop masking methods for accelerated learning, to recover mental functions lost after the injury etc. These issues were solved by such leading Soviet psychologists as B.G. Ananjev, P.J. Galperin, S.G. Gellershtein, T.I. Ginevskaya, A.V. Zaporozhets, A.N. Leontjev, A.R. Lurija, S.G. Rubinshtein etc.

In the United States after World War II psychologists got an opportunity to further find out the selection and classification techniques they had developed during World War I. Between 1944 and 1946 American Psychological Association underwent reorganization and a new Department 19, the Department of Military Psychology, appeared. Since than psychologists initially involved in assisting engineers to optimize the management seats in aircraft cockpits during World War II have become involved in the design of instrument displays, consoles, system controls, protective clothing, gunsights, combat information centers, communication equipment etc. B.F .Skinner trained pigeons to guide missiles to targets - a method that made possible the control of missiles 
before the advent of specialized electronic systems. E. Boring investigated problem of psychological adjustment to combat, moral development of soldiers.

Along with such adverse conditions as extreme sleep deprivation and the prolonged use of chemical protective clothing the effects on performance of harsh environmental conditions such as extreme heat and cold were in the focus of his interest (Cronin, 2003).

After World War II the attention to military psychology naturally increased: departments, laboratories, research groups were created. Their work was devoted to gun shooting training (P.P. Loginov), firing a machine-gun on the move (M.P. Korobejnikov), ability to read topographical maps (M.P. Gamezo), psychological foundations of shooting (D.B. Elkonin) etc. The US military psychology major research projects focused upon opportunities of human exposure: studying the features of psychotropic agents (E. Cameron), the effect of sensory deprivation (J. Hebb), and tactics of conducting interrogations (M. Orn).

The rapid expansion of the armed forces during World War II also focused attention on human behaviour within organizations. The need to identify and train leaders was of paramount importance to military structures which were based on small units in the United States. Selection, training and evaluation of leaders were identified as a special area of research for military psychology. In 1949 there were less than 3000 psychologists in the USA; by 1970 their number increased more than tenfold. According to American Psychological Association 25\% of psychologists with doctoral degrees were involved in the field of military psychology. Leaders of research projects in military sphere were such American scientists as J. Dollard, P. Likert, G. Olport etc.

As an example of analysis of battle activities as a self-regulations system we consider the functional system of P.K. Anohin. According to this approach a soldier as subject of combat activities is considered in three aspects: from his internal, psychic ability to perform combat activity, to support his actions by social and ergonomics environment, and to counteract the adverse and psychological conditions of the environment.

The need for systematic consideration of a warrior as a subject of military activity confirms the theory of functional systems by P.K. Anokhin. In order to effectively perform a warrior fighting a coordinated interaction of milestones listed on it is necessary: 
1. Incentives of battle environment (action of the enemy, his troops, changing eco-ergonomics conditions, behaviour of local population in the area of operations) must be detected and identified by military personnel, despite disorganized activity of the enemy (masking, ruse).

2. Identified military incentives must not cause an adynamic mental state of a military man (lack of will, despair, panic). Courage should be displayed

3. Warrior must recognize his position, make a decision and determine the agenda for actions (independently or with external assistance), despite the disconcerting psychological effects of the enemy. Agenda for actions must refer to the commander stated mission. Determination should be displayed.

4. Warrior must prove willful effort and act purposefully to implement the programme generated, overcome resistance, unfavourable military environment and negative emotional states.

5. Warrior must be able to properly evaluate the results of his activities and check with the mission, experience temporary failure, correct his/her program of actions and demonstrate the will to re-implement them.

6. Commanders must be capable to provide psychological support to warriors at all stages of execution of combat missions.

7. The enemy must be psychologically depressed enough in the way he could not be able to block the actions of warriors at any stage of execution of combat missions.

Postnonclassical type of rationality is beginning to emerge in the second half of the 20th century. Postnonclassical science is oriented to study self-developing systems, i.e. systems in the process of their evolution, during the transition from one level to another. Such systems include such biological objects which are considered in aspect of not only their operation but also in the aspect of their development. Objects of modern nano and biotechnology systems of modern design which take not only one or other technical and technological system, but even more evolving complex: person - technical and technological system, plus environmental system, plus cultural milieu, that accept the new technology, and the entire complex must be considered in the develop- 
ment. Such self-developing systems are modern complicated computer networks, which involve human-computer dialogue, World Wide Web, i.e. the Internet. Studying the system objects is possible only with the use of interdisciplinary and problem-oriented forms of scientific research, integrated research programmes, the synthesis of fundamental and applied research.

It is quite logical that military psychology focuses attention on social phenomena, interaction and communication, and information technologies.

Changes in modern society have brought to rapid growth in requirements for military personnel. It is related to physical training, expertise of military equipment, weapons, increasing the number of missions that the military have to solve. For qualified psychological work it is required to develop theoretical and methodological apparatus, which involves achievements of different areas of scientific knowledge: nanotechnology, biotechnology, information technologies, and cognitive neuroscience. Military-technical progress has led to address the new issues related to the preparation of soldiers: development of cognitive tools to make the effective use of information technologies, psychological training to use weapons of mass destruction etc.

In 1960s special attention was paid to psychological impact on the enemy by means of mass communication. It is known that more than 8 bln US dollars were spent in the USA on studying communication, persuasion, propaganda with active participation of social and military psychologists.

Relevant cross-cutting issue of military psychology was neuroergonomics which involved neuroscience disciplines and disciplines of studying human factors. Methodology noted that this area of scientific knowledge is sufficiently promising to reduce stress issues for the military. The consequence of this new direction is the introduction of noncontact psycho-physiological examination which allows to increase the validity of the results of psychodiagnostic research.

New modern high-tech tools are used in solving key problems for military psychological science, in particular, the technology of virtual reality. This technology makes it possible to stimulate such conditions close to reality in which a soldier could experience psycho-emotional and physiological states similar to actual circumstances. Immersion in virtual reality so perceptually surrounds the user that it reinforces his/ 
her own sense of reality and the presence of what is happening in the system. Sensory information is more vivid in virtual reality.

Virtual reality gives an opportunity to monitor user's movements (main directions and specific body positions, facial expression and gestures) providing full information about reactions to environment. Virtual reality is a particular structure that helps to regulate user's experience (to change design of the virtual world in accordance with the experimental purposes), adjust on-line user's actions.

A permanent change of the conditions where the soldier is found raises a question of constructing bases for military psychological science in the context of post-classical paradigm. As a basis for national military psychology is user's activity in relation to the situation in postclassical period. Apparent is the need to consider soldier as a complete system (individual - personality - actor) who reacts to external and internal changes of not only by separate parts of his/her psyche (mental processes, states, features) but as a single whole mediating his/her actions, deeds, behaviour, attitudes by personal features. For understanding a human figure it is necessary to allot such features of activity as awareness, motivation and ergics. The awareness of the figure indicates the presence of his/her dynamic cognitive model that reflects information regarding the object, the subject and the process of activity. With regard to military activities this means that each soldier should have a clear notion about the enemy (his purported goals, leading motives, psychological capabilities and vulnerabilities, psychological state, strengths and weaknesses of his tactics, possibility of military equipment and weapons, social basis), about forthcoming combat missions (aim, place in the overall system of combat mission, procedure of actions, tools of achievements, control signals and communication, psychological factors and conditions which are characteristic of and possible psychological phenomena), about himself/herself (the sequence of actions, information about means, criteria, types of self-diagnostics, variants of psychological support of colleagues and psychological selfregulation and condition of use).

Motivated military activity reflects the degree of combination of soldier's needs and purposes of his actions. It is well known that in order to transfer the actions into the activity the need should be "objective" in the motive. Motive as a driving force of human behaviour fulfills three functions: motivation to work, giving it direction and meaning. 
Like any complex activity military activity has multiple motivations. M.I. Dyachenko distinguished three types of motivation: broad social motives (faith, love to motherland, hatred to enemy, sense of duty etc), collective group-motives (partnership, mutual assistance, fear of being rejected by the group), individual motives (desire to distinguish oneself, to receive an award, to test one's capacities, to earn money, superstition etc.). The combat experience has shown that partnership is the most easily produced motive and is stable in functioning. However, during the prolonged combat mission social motives are more effective.

Volitional basis of activity is understood as a human ability to choose aim-motive through awareness of correspondence of purpose action to mental principles and norms of individual and military group. Action on the principle of "the end justifies the means" exhausts the moral forces of the soldier, demoralizes his/her personality, gives rise to negative social psychological phenomena. In this regard establishing such conditions under which a soldier could choose the purpose of his activity, creating a system of internal regulation of military activity must be essential to the psychological support of combat operations. Also in addition it is necessary to take into account the structure of military activity during methodological analysis. It is possible to distinguish three layers in the soldier's environment: macrosocial (the world community, the armed forces, local population, the enemy); microsocial (collective military unit) and ergonomic (natural geographic, technical and technological environment). As a subject of military operations the object of psychological support should be considered a dynamic, self-developing system but not an individual soldier or a military group.

\section{References}

D’jachenko, M.I. (1966). Psikhologicheskaja podgotovka sovetskih voinov $k$ boevym dejstvijam v uslovijah sovremennoj vojny [Psychological preparation of the Soviet soldiers for combat in modern warfare]. Moscow.

Zykov, A. (1987). Kak i chem upravljajutsja ljudi. Opyt voennoj psikhologii [What and how people are managed. Experience in military psychology]. St. Petersburg.

Stepin, V.S. (2009). Klassika, neklassika, postneklassika: kriterii razlichenija [Classics, nonclassics, postnonclassics: criteria for distinguishing]. In Postneklassika: filosofja, nauka, kul'tura [Postnonclassics: philosophy, science, culture] (p. 263). Moscow. 
Talankin, A. (1927). K voprosu o voennoj refleksologii [On the question of military reflexology]. Vojna i revoljucija [War and Revolution], 11.

Hahan'jan, G. (1929). Osnovy voennoj psikhologii [Foundations of military psychology]. Moscow, Leningrad: Gosizdat.

Cronin, C.C. (2003). Military psychology: An introduction. USA.

Janelle, C.M., \& Hatfield, B.D. (2008). Visual Attention and Brain Processes That Underlie Expert Performance: Implications for Sport and Military Psychology. Military Psychology, 20. 39-69.

Matthews, M.D. (2008). Toward a Positive Military Psychology. Military Psychology, 20.

Killion, T.H., \& Bury, S.J. (2009). United States Army Science and Technology: Sustaining Soldier Performance. Military Psychology, 21. 1-19.

Summers, F. (2008). Making Sense of the APA: A History of the Relationship Between Psychology and the Military. Psychoanalytic Dialogues, 18, 614-637. 